\title{
Microreview
}

\section{mlo-based powdery mildew immunity: silver bullet or simply non-host resistance?}

\author{
MATT HUMPHRY, CHIARA CONSONNI AND RALPH PANSTRUGA* \\ Max-Planck Institute for Plant Breeding Research, Department of Plant-Microbe Interactions, Carl-von-Linné-Weg 10, D-50829 Köln, Germany
}

\section{SUMMARY}

Durability and effectiveness against all genetic variants of a microbial species are hallmarks of so-called plant 'non-host' resistance. Highly effective immunity of monocotyledonous barley against the fungal powdery mildew pathogen, which is conferred by loss-of-function mutant alleles of the barley Mlo locus, likewise is a durable and broad-spectrum type of resistance. Although this was long considered as being a barley-specific phenomenon, recent findings indicate that mlo resistance can also occur in the distantly related dicotyledonous species Arabidopsis thaliana. Shared histological and phytopathological characteristics plus a conserved requirement for a set of genes in Arabidopsis mlo and non-host powdery mildew resistance indicate a potential common mechanism for these two seemingly distinct types of immunity.

\section{A TIDY HOUSE, A TIDY MIND}

To simplify their lives, humans love to classify and categorize their surrounding world. Scientists are no exception in this respect, as can be most obviously seen from the taxonomy of living organisms. Plant pathologists also like to organize their subject: in plants, various seemingly distinct forms of defence have been discovered. Based on the range of microorganisms covered by a particular type of immunity, its underlying molecular components discovered so far and other characteristics, these types of resistance have been operationally categorized in various classes. These include 'basal defence' (Nomura et al., 2005), 'resistance $(R)$ gene-mediated immunity' (also referred to as isolate- or race-specific resistance; Martin et al., 2003), 'systemic acquired resistance' (Metraux et al., 2002), 'quantitative (also termed polygenic) resistance' (Lindhout, 2002) and 'non-host-resistance'

* Correspondence: Tel.: +49 2215062 316; Fax: +49 2215062 353;

E-mail: panstrug@mpiz-koeln.mpg.de
(Nürnberger and Lipka, 2005). Owing to its recessive mode of inheritance, the pathogen-specific impact and its uncommon durability in agricultural settings, broad-spectrum powdery mildew resistance conferred by barley loss-of-function mlo alleles has been considered until now to be another and hitherto unique type of disease resistance (Jørgensen, 1992, 1994).

Although historically the above classifications have been quite stringent, plant pathologists have recently begun to appreciate major genetic and molecular intersections between the various types of plant immunity. For example, genes such as NPR1 and EDS1/PAD4, which encode key components of salicylic acidmediated plant defence signalling, were found to be essential for various types of disease resistance (Aarts et al., 1998; Lipka et al., 2005; Rairdan and Delaney, 2002). Likewise, global transcription profiling revealed similar sets of genes whose expression is altered during basal defence, $R$ gene-triggered immunity and in non-host interactions (Caldo et al., 2004; Navarro et al., 2004; Zimmerli et al., 2004). On this note, we hypothesize here that $\mathrm{mlo}$ resistance is mechanistically identical to non-host resistance.

\section{PLANT NON-HOST RESISTANCE: KEEPING THE BUGS AT BAY}

Most microorganisms fail to colonize most plant species successfully because plants possess an elaborate surveillance system that readily uncovers the presence of potentially pathogenic agents by the occurrence of conserved microbial molecules, so-called pathogen-associated molecular patterns (PAMPs) (Nürnberger and Lipka, 2005). This surveillance system is based on membrane-localized receptors that guard the apoplastic space as well as on presumably intracellular pattern recognition receptors that monitor the cytoplasm. PAMP recognition triggers (a) signalling cascade(s) that ultimately leads to activation of a bouquet of defences that suffice to reject the attempted attacks of most microbes. This capacity is frequently also referred to as 'innate immunity' or 'non-host resistance' (Nürnberger and Lipka, 2005). Few bacteria and fungi have evolved means to overcome this barrier and, as a consequence, few are able to colonize and 
reproduce on a given plant species. The molecular mechanisms underlying the presumptive defence suppression that is required to overcome plant innate immunity are, however, elusive for most parasites (Nomura et al., 2005; Panstruga, 2003). It is thought that the plant's multifaceted detection and response machinery renders this non-specific type of immunity particularly effective and durable (Nürnberger and Lipka, 2005; Thordal-Christensen, 2003). The evolutionary success of non-host resistance can be judged from the fact that indeed most plants are resistant to most microorganisms.

\section{MLO RESISTANCE: A BIG HIT IN POWDERY MILDEW IMMUNITY}

In the course of evolution, powdery mildew fungi evolved means to overcome non-host resistance in a particular plant species (referred to as the plant host species) and became able to cause disease. Barley, for example, is susceptible to the ascomycete Blumeria graminis f.sp. hordei (Bgh), a powdery mildew pathogen with a very narrow host spectrum that fails to colonize any other plant species. Genetic data indicate that the presence of a particular protein of the barley host plant, the MLO protein, is a prerequisite for successful colonization by the powdery mildew fungus (Büschges et al., 1997; Jørgensen, 1992). In the absence of MLO, such as in barley mlo mutants, germinated fungal spores fail to enter epidermal host cells; as a consequence, the mutant plant is resistant. This phenomenon was originally discovered more than 60 years ago when the first mlo mutant was isolated in a forward genetic screen in barley (Freisleben and Lein, 1942). Subsequently, many mlo alleles were recovered (e.g. Jørgensen, 1976), and it was found that $m / o$ resistance is effective against all known isolates of $B g h$ but does not affect a range of other foliar pathogens (Jørgensen, 1977). Following breeding into barley elite varieties, mlo resistance has been successfully employed in agriculture for more than 25 years (Lyngkjaer et al., 2000). Despite its success in barley cultivation, until recently there was no report regarding a similarly effective powdery mildew resistance locus in any other plant species. For a long time, barley $\mathrm{mlo}$ resistance has thus been considered as a potentially unique type of plant immunity (Jørgensen, 1992, 1994). However, the recent finding that $m / o$ resistance with comparable characteristics as in barley can also occur in the dicotyldenous reference plant Arabidopsis thaliana indicates that mlo-based powdery mildew resistance is not a barley-specific phenomenon and probably may be inducible in any higher plant species (Consonni et al., 2006).

It is therefore tempting to speculate that the absence of reports of powdery mildew-resistant mutants with mlo-like characteristics in other plant species is either due to a lack of respective forward genetic screens or a potential functional redundancy of multiple MLO isoforms in some plant species. Evidence for the latter comes from a recent analysis of the situation in $A$. thaliana. In the dicotyledonous reference species, three out of $15 \mathrm{MLO}$ genes encode sequence-related proteins with partially overlapping functions in the modulation of defence responses to powdery mildews (Consonni et al., 2006). It is, however, worthwhile mentioning that pea and tomato accessions have been identified which exhibit powdery mildew resistance that is reminiscent of mlo-based immunity (Bai et al., 2005; Fondevilla et al., 2006). It remains to be seen whether resistance in these accessions is in fact due to natural loss-of-function polymorphisms in $M L O$ genes, as previously found in the Ethiopian barley landrace carrying the m/o-11 allele (Piffanelli et al., 2004).

\section{KNOCK, KNOCK (YOU CAN'T COME IN)}

Grass powdery mildews such as Bgh or its close relative, the wheat powdery mildew fungus Blumeria graminis f.sp. tritici $(B g t)$, have been recently employed in a range of studies to unravel the molecular principles of (powdery mildew) non-host resistance in $A$. thaliana (Assaad et al., 2004; Collins et al., 2003; Lipka et al., 2005; Stein et al., 2006; Yun et al., 2003; Zimmerli et al., 2004). When inoculated on Arabidopsis wild-type plants, most germinated Bgh or Bgt spores fail to enter the leaf epidermal cells of the dicotyledonous plant species. Reminiscent of $\mathrm{mlo}$ resistance (Skou, 1982), pathogen arrest in these incompatible interactions usually coincides with the formation of callosecontaining papillae (Thordal-Christensen, 2003; Fig. 1). In the few cases where the pathogen successfully invades an epidermal cell and establishes its feeding organ, designated the haustorium, a cell death response is commonly triggered that terminates any further development of the fungal parasite (Collins et al., 2003; Lipka et al., 2005; Thordal-Christensen, 2003; Yun et al., 2003). Consequently, post-invasive hyphal growth (microcolony formation) represents an extremely rare phenomenon in this non-host interaction (Lipka et al., 2005). In summary, reminiscent of barley mlo mutants, non-host resistance of Arabidopsis to the non-adapted grass powdery mildews, Bgh and Bgt, is largely determined at the pre-invasive stage.

\section{THE USUAL SUSPECTS? BY NO MEANS!}

Salicylic acid (SA), jasmonic acid (JA) and ethylene (ET) are messenger molecules that define well-characterized defence signalling pathways in A. thaliana (Hammond-Kosack \& Parker, 2003). SA-mediated signalling, for example, has been shown to play a crucial role in $R$-gene mediated immunity, systemic acquired resistance and basal defence to adapted biotrophic pathogens (Glazebrook, 2005). By contrast, JA and ET are thought to mediate signalling during basal defence against necrotrophic pathogens (Glazebrook, 2005). A comprehensive analysis employing a range of mutants defective in the SA-, JA- or ET-mediated defence signalling pathways revealed that neither of the three 
Fig. 1 Arrest of fungal penetration attempts coincident with the formation of callose-containing papillae. The micrographs depict the attempted penetration of an epidermal cell of an Arabidopsis wild-type plant by the non-adapted Bgh pathogen (left) or of an Arabidopsis m/o2 mutant genotype by the usually compatible powdery mildew fungus Golovinomyces orontii (right). Deposition of callose in cell wall appositions (white arrowheads) is highlighted by UV epifluorescence upon aniline blue staining; fungal structures [spore (s) and appressorial germ tubes] were highlighted by Coomassie Blue staining. Scale bar, $25 \mu \mathrm{m}$.
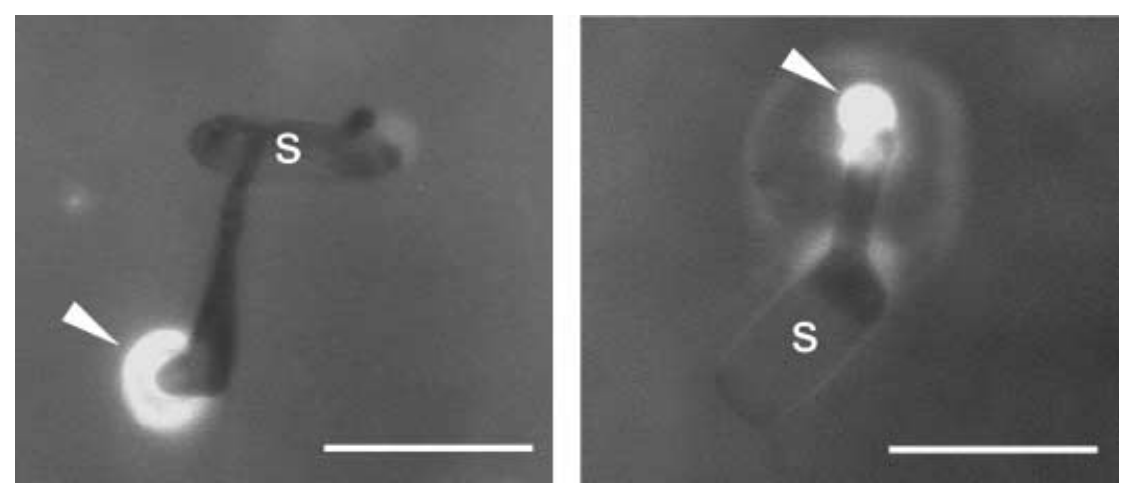

signal transduction pathways significantly contributes to penetration resistance against the non-adapted grass powdery mildew Bgh (Zimmerli et al., 2004). A similar study employing double mutants defective in AtMLO2 and any of the three signalling pathways (using a comparable set of mutants as described above) revealed that mlo-mediated resistance in Arabidopsis against the adapted powdery mildew species Golovinomyces orontii and Golovinomyces (formerly Erysiphe) cichoracearum likewise does not require SA-, JA- or ET-mediated signalling (Consonni et al., 2006). Taken together, it appears that in $A$. thaliana powdery mildew non-host resistance and mlo-based immunity both function largely independent of the common defence signalling pathways described for this model plant species.

Transcript profiling of plant responses to adapted and nonadapted mildews, however, has revealed that very few genes, including plant defensins such as PDF1.2, were uniquely and transiently induced at around 1 day following inoculation with $B g h$, suggesting that the JA/ET pathways may play a role in basal defence responses that the adapted mildews either evade or fail to elicit (Zimmerli et al., 2004). Similarly, transcript profiling of G. cichoracearum-inoculated plants also revealed a transient peak of PDF1.2 expression in pmr2 (= Atm/o2) mutants, but not in wild-type plants, at approximately the same time point as that observed by Vogel and Somerville (2000). This suggests that the adapted mildew fungus may elicit the same unique responses in Atmlo2 individuals as Bgh in Arabidopsis wild-type plants.

\section{PENNING DOWN THE COMPONENTS OF ARABIDOPSIS NON-HOST RESISTANCE}

Forward genetic screens in $A$. thaliana have thus far identified three genes (PENETRATION 1-3) that are each required for the highly effective penetration resistance against non-adapted powdery mildews. Loss-of-function mutations in any of the three genes, PEN1, PEN2 or PEN3, result in enhanced Bgh entry rates into Arabidopsis leaf epidermal cells (Collins et al., 2003; Lipka et al., 2005; Stein et al., 2006), demonstrating that all three genes are necessary to mount an effective defence response against Bgh at the cell periphery. PEN1 encodes a syntaxin, a member of the super-family of SNARE domain proteins, and is assumed to be involved in membrane fusion events during exocytosis at the plasma membrane (Collins et al., 2003). PEN2 encodes a peroxisome-associated glycosyl hydrolase (Lipka et al., 2005), while PEN3 has been found to encode an ATP-binding cassette multi-drug transporter (Stein et al., 2006). Intriguingly, full mlo resistance in Arabidopsis requires the very same set of genes as powdery mildew non-host resistance. Host cell entry, but not conidiophore formation (asexual sporulation), is restored in Atmlo2 pen1 double mutants (Consonni et al., 2006). This finding is consistent with previous data from barley, where the orthologue of the Arabidopsis PEN1 syntaxin, barley ROR2, has been shown to be required for full mlo resistance (Collins et al., 2003; Freialdenhoven et al., 1996). Barley genes Ror2 and Ror1 were originally discovered in a genetic suppressor screen for compromised mlo resistance, and mutations in either gene partially (ror2) or fully (ror1 alleles) abolish immunity against powdery mildew in mlo genotypes (Freialdenhoven et al., 1996). Although Ror2 has been shown to encode a syntaxin orthologous to Arabidopsis PEN1 (Collins et al., 2003), the identity of Ror1 has remained elusive to date. Contrary to Atmlo2 pen1 mutants, Atmlo2 pen2 or Atmlo2 pen 3 double mutants not only exhibit restored pathogen entry rates but also wild-type-like conidiation (Consonni et al., 2006).

\section{ENCORE: FURTHER SIMILARITIES BETWEEN MLO AND NON-HOST RESISTANCE}

Identification of the PEN1/ROR2 syntaxins as key mediators of mlo and non-host immunity suggested a chief role for exocytosis in both types of resistance (Collins et al., 2003). Consistent with this hypothesis, transient gene silencing experiments in single barley leaf epidermal cells uncovered a further SNARE domain protein, the SNAP25 homologue HvSNAP34, as an additional contributor to both types of immunity (Collins et al., 2003; Douchkov et al., 2005). In yeast and animal cells, syntaxins and SNAP25 interact with each other to form the so-called binary 
SNARE complex of prototypical eukaryotic SNARE complexes. Further supporting a role for transport processes in both types of resistance, pharmacological and/or genetic interference with actin cytoskeleton function partially abolishes host cell entry by adapted (mlo genotype) or non-adapted mildew species (Kobayashi et al., 1997; Yun et al., 2003; M. Miklis et al., unpublished results).

Transient gene expression studies in single barley leaf epidermal cells revealed that over-expression of the presumed apoptosis suppressor, Bax inhibitor 1, partially compromises mlo resistance to Bgh (Hückelhoven et al., 2003). Although a plausible explanation for this phenomenon is still lacking, transient over-expression of Bax inhibitor 1 likewise affects non-host immunity to Bgt (Eichmann et al., 2004). Additionally, transient over-expression of a constitutive active variant of a barley calcium-dependent protein kinase (CDPK) isoform also partially impairs both mlo and non-host resistance in single barley leaf epidermal cells, further corroborating a mechanistic link between mlo resistance and non-host immunity (T. Diehl et al., unpublished results).

\section{MLO RESISTANCE AND NON-HOST IMMUNITY: TWO FACES OF THE SAME COIN}

When comparing histological and phytopathological characteristics as well as genetically defined requirements of powdery mildew non-host resistance and mlo-based immunity in barley and Arabidopsis, it becomes evident that both types of resistance share analogous features (Table 1). We therefore hypothesize that powdery mildew non-host resistance and mlo-based immunity are mechanistically identical. The absence of the key host protein for successful cell entry, MLO, appears to convert a compatible interaction between an adapted powdery mildew pathogen and its respective host plant into a genuine non-host interaction. It seems that on mlo mutants, the fungal parasite faces the same hurdles and obstacles (Thordal-Christensen, 2003) as any non-adapted powdery mildew fungus. This hypothesis provides a plausible explanation as to why mlo-based resistance is in fact broad-spectrum and durable. It also suggests that any mutation that affects non-host resistance should also compromise $m l o$ immunity and vice versa. This prediction has been shown to be true for the three Arabidopsis PEN genes known so far, but it remains to be shown whether it also holds true for the recently cloned PEN4 gene (M. Lim and S. Somerville, personal communication). In barley, mutations in Ror1, a gene required for mlo resistance (see above; Freialdenhoven et al., 1996) also affect defence against at least one further non-adapted pathogen species, the rice blast fungus Magnaporthe grisea (Jarosch et al., 2005), and it might be that the weak phenotype of the single existing ror2 allele masks obvious phenotypes of this mutant in interactions with non-adapted pathogens. Thus, reminiscent of the Arabidopsis PEN genes (see above), barley Ror1 may encode a further component with a role in both mlo immunity and basal defence/non-host resistance.

The fact that the presence of MLO is indeed required to turn a non-host interaction into a compatible interaction is consistent with the hypothesis that the adapted powdery mildew pathogen is able to target MLO for manipulation of innate immunity (Panstruga, 2005). It is currently thought that MLO proteins function as regulatory components of plant secretory processes involving SNARE domain proteins such as the above mentioned Arabidopsis PEN1 and barley ROR2 syntaxins (Panstruga, 2005). The low level of successful cell entry by non-adapted mildew species may consequently reflect the extensive inability of the

Table 1 Comparison between mlo and non-host powdery mildew resistance.

\begin{tabular}{|c|c|c|c|}
\hline & mlo resistance & Non-host resistance & References \\
\hline Resistance spectrum & broad $^{*} \dagger$ & broad $^{*} \dagger$ & Jørgensen (1977), Consonni et al. (2006) \\
\hline Constancy & durablet & durable* $\dagger$ & Jørgensen (1992), Nürnberger and Lipka (2005) \\
\hline Stage of fungal pathogenesis primarily affected & plant cell entry* $\dagger$ & plant cell entry* $\dagger$ & Consonni et al. (2006), Collins et al. (2003) \\
\hline $\begin{array}{l}\text { Pathogen arrest associated with formation of } \\
\text { callose-containing cell wall appositions (papillae) }\end{array}$ & yes $^{*} \dagger$ & yes $^{*} \dagger$ & Skou (1982), Collins et al. (2003), Fig. 1 (this work) \\
\hline Dependent on SA-, JA- or ET-mediated defence signalling & no* & no* & Consonni et al. (2006) \\
\hline Dependent on actin cytoskeleton function & yest & yes* & $\begin{array}{l}\text { Kobayashi et al. (1997), Yun et al. (2003), } \\
\text { M. Miklis et al. (unpublished results) }\end{array}$ \\
\hline $\begin{array}{l}\text { Dependent on PEN1, PEN2 and PEN3 (Arabidopsis) or } \\
\text { ROR2 (the barley orthologue of PEN1) function }\end{array}$ & yes* $\dagger$ & yes* $\dagger$ & $\begin{array}{l}\text { Consonni et al. (2006), Collins et al. (2003), } \\
\text { Lipka et al. (2005), Stein et al. (2006), } \\
\text { Freialdenhoven et al. (1996), Jarosch et al. (2005) }\end{array}$ \\
\hline Dependent on SNAP34 function & yest & yest & Collins et al. (2003), Douchkov et al. (2005) \\
\hline $\begin{array}{l}\text { Resistance compromised by over-expression of the } \\
\text { apoptosis suppressor BAX inhibitor } 1\end{array}$ & yest & yest & Hückelhoven et al. (2003), Eichmann et al. (2004) \\
\hline
\end{tabular}

*Based on findings in Arabidopsis thaliana.

†Based on findings in barley (Hordeum vulgare). 
fungal pathogen to exploit a foreign (heterologous) MLO protein for the suppression of secretion-associated defence processes at the plant cell periphery. This assumption is supported by the findings that (i) mlo resistance not only affects the adapted but also non-adapted powdery mildew species (Consonni et al., 2006; Peterhänsel et al., 1997) and (ii) over-expression of barley Mlo enhances susceptibility to the non-adapted wheat powdery mildew, Bgt (Elliott et al., 2002). In conclusion, it appears that there is no longer any mystery associated with mlo resistance as it simply seems to correspond to common non-host penetration resistance. If this hypothesis holds true, then research into $\mathrm{mlo}$ immunity and non-host resistance will continue to complement each other.

\section{ACKNOWLEDGEMENTS}

Research in the laboratory of R.P. is supported by grants from the Deutsche Forschungsgemeinschaft DFG (PA 861/4, SFB 670) and the Max-Planck Society.

\section{REFERENCES}

Aarts, N., Metz, M., Holub, E., Staskawicz, B.J., Daniels, M.J. and Parker, J.E. (1998) Different requirements for EDS1 and NDR1 by disease resistance genes define at least two $R$. gene-mediated signaling pathways in Arabidopsis. Proc. Natl Acad. Sci. USA, 95, 10306-10311.

Assaad, F.F., Qiu, J.L., Youngs, H., Ehrhardt, D., Zimmerli, L., Kalde, M., Wanner, G., Peck, S.C., Edwards, H., Ramonell, K., Somerville, C.R. and Thordal-Christensen, H. (2004) The PEN1 syntaxin defines a novel cellular compartment upon fungal attack and is required for the timely assembly of papillae. Mol. Biol. Cell, 15, 5118-5129.

Bai, Y.L., van der Hulst, R., Bonnema, G., Marcel, B.C., Meijer-Dekens, F., Niks, R.E. and Lindhout, P. (2005) Tomato defense to Oidium neolycopersici: Dominant $\mathrm{O} /$ genes confer isolate-dependent resistance via a different mechanism than recessive $\mathrm{Ol}-2$. Mol. Plant-Microbe Interact. 18, 354-362.

Büschges, R., Hollricher, K., Panstruga, R., Simons, G., Wolter, M., Frijters, A., van Daelen, R., van der Lee, T., Diergaarde, P., Groenendijk, J., Töpsch, S., Vos, P., Salamini, F. and Schulze-Lefert, P. (1997) The barley Mlo gene: a novel control element of plant pathogen resistance. Cell, 88, 695-705.

Caldo, R.A., Nettleton, D. and Wise, R.P. (2004) Interaction-dependent gene expression in Mla-specified response to barley powdery mildew. Plant Cell, 16, 2514-2528.

Collins, N.C., Thordal-Christensen, H., Lipka, V., Bau, S., Kombrink, E., Qiu, J.L., Hückelhoven, R., Stein, M., Freialdenhoven, A., Somerville, S.C. and Schulze-Lefert, P. (2003) SNARE-protein-mediated disease resistance at the plant cell wall. Nature, 425, 973-977.

Consonni, C., Humphry, M.E., Hartmann, H.A., Livaja, M., Durner, J., Westphal, L., Vogel, J., Lipka, V., Kemmerling, B., Schulze-Lefert, P., Somerville, S.C. and Panstruga, R. (2006) Conserved requirement for a plant host cell protein in powdery mildew pathogenesis. Nature Genet. 38, 716-720.

Douchkov, D., Nowara, D., Zierold, U. and Schweizer, P. (2005) A high-throughput gene-silencing system for the functional assessment of defense-related genes in barley epidermal cells. Mol. Plant-Microbe Interact. 18, 755-761.

Eichmann, R., Schultheiss, H., Kogel, K.H. and Hückelhoven, R. (2004) The barley apoptosis suppressor homologue bax inhibitor-1 compromises nonhost penetration resistance of barley to the inappropriate pathogen Blumeria graminis f.sp. tritici. Mol. Plant-Microbe Interact. 17, 484-490.

Elliott, C., Zhou, F.S., Spielmeyer, W., Panstruga, R. and Schulze-Lefert, P. (2002) Functional conservation of wheat and rice Mlo orthologs in defense modulation to the powdery mildew fungus. Mol. Plant-Microbe Interact. 15, 1069-1077.

Fondevilla, S., Carver, T.L.W., Moreno, M.T. and Rubiales, D. (2006) Macroscopic and histological characterisation of genes er1 and er2 for powdery mildew resistance in pea. Eur. J. Plant Pathol. 115, 309-321.

Freialdenhoven, A., Peterhänsel, C., Kurth, J., Kreuzaler, F. and Schulze-Lefert, P. (1996) Identification of genes required for the function of non-race-specific mlo resistance to powdery mildew in barley. Plant Cell. 8, 5-14.

Freisleben, R. and Lein, A. (1942) Über die Auffindung einer mehltauresistenten Mutante nach Röntgenbestrahlung einer anfälligen reinen Linie von Sommergerste. Naturwissenschaften, 30, 608.

Glazebrook, J. (2005) Contrasting mechanisms of defense against biotrophic and necrotrophic pathogens. Annu. Rev. Phytopathol. 43, 205-227.

Hammond-Kosack, K.E. and Parker, J.E. (2003) Deciphering plantpathogen communication: fresh perspectives for molecular resistance breeding. Curr. Opin. Biotechnol. 14, 177-193.

Hückelhoven, R., Dechert, C. and Kogel, K.H. (2003) Overexpression of barley BAX inhibitor 1 induces breakdown of mlo-mediated penetration resistance to Blumeria graminis. Proc. Natl Acad. Sci. USA, 100, 5555-5560.

Jarosch, B., Collins, N.C., Zellerhoff, N. and Schaffrath, U. (2005) RAR1, ROR1, and the actin cytoskeleton contribute to basal resistance to Magnaporthe grisea in barley. Mol. Plant-Microbe Interact. 18, 397-404.

Jørgensen, J.H. (1976) Identification of powdery mildew resistant barley mutants and their allelic relationship. In: Barley Genetics III (Gaul, H., ed.), pp. 446-455. München: Karl Thiemig Verlag.

Jørgensen, J.H. (1977) Spectrum of resistance conferred by ML-O powdery mildew resistance genes in barley. Euphytica, 26, 55-62.

Jørgensen, J.H. (1992) Discovery, characterization and exploitation of Mlo powdery mildew resistance in barley. Euphytica, 63, 141-152.

Jørgensen, J.H. (1994) Genetics of powdery mildew resistance in barley. Crit. Rev. Plant Sci. 13, 97-119.

Kobayashi, Y., Kobayashi, I., Funaki, Y., Fujimoto, S., Takemoto, T. and Kunoh, H. (1997) Dynamic reorganization of microfilaments and microtubules is necessary for the expression of non-host resistance in barley coleoptile cells. Plant J. 11, 525-537.

Lindhout, P. (2002) The perspectives of polygenic resistance in breeding for durable disease resistance. Euphytica, 124, 217-226.

Lipka, V., Dittgen, J., Bednarek, P., Bhat, R., Wiermer, M., Stein, M., Landtag, J., Brandt, W., Rosahl, S., Scheel, D., Llorente, F., Molina, A., Parker, J., Somerville, S. and Schulze-Lefert, P. (2005) Pre- and postinvasion defenses both contribute to nonhost resistance in Arabidopsis. Science, 310, 1180-1183.

Lyngkjaer, M.F., Newton, A.C., Atzema, J.L. and Baker, S.J. (2000) The Barley mlo-gene: an important powdery mildew resistance source. Agronomie, 20, 745-756.

Martin, G.B., Bogdanove, A.J. and Sessa, G. (2003) Understanding the functions of plant disease resistance proteins. Annu. Rev. Plant Biol. 54 23-61. 
Metraux, J.P., Nawrath, C. and Genoud, T. (2002) Systemic acquired resistance. Euphytica, 124, 237-243.

Navarro, L., Zipfel, C., Rowland, O., Keller, I., Robatzek, S., Boller, T. and Jones, J.D.G. (2004) The transcriptional innate immune response to flg22. interplay and overlap with Avr gene-dependent defense responses and bacterial pathogenesis. Plant Physiol. 135, 1113-1128.

Nomura, K., Melotto, M. and He, S.Y. (2005) Suppression of host defense in compatible plant-Pseudomonas syringae interactions. Curr. Opin. Plant Biol. 8, 361-368.

Nürnberger, T. and Lipka, V. (2005) Non-host resistance in plants: new insights into an old phenomenon. Mol. Plant Pathol. 6, 335-345.

Panstruga, R. (2003) Establishing compatibility between plants and obligate biotrophic pathogens. Curr. Opin. Plant Biol. 6, 320-326.

Panstruga, R. (2005) Serpentine plant MLO proteins as entry portals for powdery mildew fungi. Biochem. Soc. Trans. 33, 389-392.

Peterhänsel, C., Freialdenhoven, A., Kurth, J., Kolsch, R. and SchulzeLefert, P. (1997) Interaction analyses of genes required for resistance responses to powdery mildew in barley reveal distinct pathways leading to leaf cell death. Plant Cell, 9, 1397-1409.

Piffanelli, P., Ramsay, L., Waugh, R., Benabdelmouna, A., D'Hont, A., Hollricher, K., Jorgensen, J.H., Schulze-Lefert, P. and Panstruga, R. (2004) A barley cultivation-associated polymorphism conveys resistance to powdery mildew. Nature, $430,887-891$.
Rairdan, G.J. and Delaney, T.P. (2002) Role of salicylic acid and NIM1/ NPR1 in race-specific resistance in Arabidopsis. Genetics, 161, 803-811.

Skou, J.P. (1982) Callose formation responsible for the powdery mildew resistance in barley with genes in the ml-o locus. Phytopathol Z-J. Phytopathol. 104, 90-95.

Stein, M., Dittgen, J., Sanchez-Rodriguez, C., Hou, B.H., Molina, A., Schulze-Lefert, P., Lipka, V. and Somerville, S. (2006) Arabidopsis PEN3/PDR8, an ATP binding cassette transporter, contributes to nonhost resistance to inappropriate pathogens that enter by direct penetration. Plant Cell, 18, 731-746.

Thordal-Christensen, H. (2003) Fresh insights into processes of nonhost resistance. Curr. Opin. Plant Biol. 6, 351-357.

Vogel, J. and Somerville, S. (2000) Isolation and characterization of powdery mildew-resistant Arabidopsis mutants. Proc. Natl. Acad. Sci. USA, 97, 1897-1902.

Yun, B.W., Atkinson, H.A., Gaborit, C., Greenland, A., Read, N.D., Pallas, J.A. and Loake, G.J. (2003) Loss of actin cytoskeletal function and EDS1 activity, in combination, severely compromises non-host resistance in Arabidopsis against wheat powdery mildew. Plant J. 34, 768-777.

Zimmerli, L., Stein, M., Lipka, V., Schulze-Lefert, P. and Somerville, S. (2004) Host and non-host pathogens elicit different jasmonate/ethylene responses in Arabidopsis. Plant J. 40, 633-646. 